\title{
PELATIHAN PENINGKATAN KEAHLIAN PROGRAM PERANCANGAN MULTIMEDIA DI F18 DIGITAL PRINTING PALEMBANG
}

\author{
Aji Windu Viatra'), Bobby Halim²), K. Ghazali'3) \\ 1)233)Fakultas Ilmu Pemerintahan dan Budaya. Jurusan Desain Komunikasi Visual, \\ Universitas Indo Global Mandiri, Palembang. \\ Jln. Jenderal Sudirman No. 629 Km 4, Palembang \\ Telp. (0711) 322705 - 322706 Fax. (0711) 357754, Website : www.igm.ac.id \\ Email : w1ndoe@yahoo.com ${ }^{1)}$ bhaliem@gmail.com ${ }^{2}$, igo 20002000@yahoo.co.id $\left.{ }^{3}\right)$
}

\begin{abstract}
ABSTRAK
Pelatihan peningkatan keahlian program perancangan multimedia dengan pemanfaatan program Adobe Premiere bertujuan untuk memberikan keterampilan dalam pembuatan multimedia yang menarik dengan cara yang relatif mudah. Penguasaan kemampuan perancangan media iklan elektronik dengan aplikasi media LED display screen yang dikuasai oleh sumber daya manusia program multimedia oleh para desainer grafis diharapkan akan memicu minat untuk lebih bersemangat dalam mengembangkan kemampuan, dan pada akhirnya akan meningkatkan kualitas perancangan multimedia digital secara keseluruhan.

Metode yang diterapkan dalam kegiatan ini adalah Metode presentasi mengenai pengenalan software, kemanfaataannya, dan penerapannya dalam pembuatan media pembelajaran interaktif, metode workshop/demonstrasi mengenai pengoperasionalisasian program dan metode praktik yaitu pembuatan secara teknis tip dan trik secara langsung bagi peserta sesuai dengan sub kerja masing-masing dengan pemanfaatan program-program Adobe.

Metode evaluasi dengan mengamati perbedaan kemampuan desainer sebelum dan setelah pelatihan. Hasil yang dicapai terlihat peningkatan kemampuan yang cukup signifikan dibanding dengan sebelum dilatih, sehingga dapat disimpulkan bahwa kegiatan ini berhasil meningkatkan kemampuan peserta dan memicu motifasi etos kerja untuk selalu berpikir kreatif dan artistik. Evaluasi hasil dilihat dari penilaian tugas praktik yang menggambarkan keberhasilan materi yang telah disajikan. Selain itu juga dicermati kinerja dan partisipasi para peserta. Program pelatihan ini diharapkan terus diadakan pada setiap jenis usaha sejenis karena sangat dirasakan manfaatnya untuk meningkatkan kualitas media grafis yang lebih kreatif.
\end{abstract}

Kata kunci : Pelatihan, Multimedia, Program Adobe, Desain Grafis, Digital Printing

\section{PENDAHULUAN}

Perkembangan teknologi dan sistem pendidikan yang semakin pesat sangat berpengaruh terhadap segala bentuk usaha masyarakat. Saat ini banyak wirausaha telah melakukan banyak peningkatan dalam hal pelayanan kepada masyarakat, termasuk salah satunya adalah pelayanan dalam hal penciptaan produk dan pemberian informasi. Inovasi produk-produk berupa media dan informasi harus segera bisa diserap oleh masyarakat secepatnya mengingat adanya tenggat waktu dan masa. Media produk dan Informasi yang diberikan akan sangat berguna bagi masyarakat untuk itu perlu adanya sosialisasi secara cepat dan tepat.

Sistem pendidikan dewasa ini telah mengalami perkembangan kemajuan yang sangat cepat. Zahara Idris (1987) mengemukakan bahwa sistem adalah kesatuan yang terdiri atas komponenkomponen atau elemen-elemen atau unsur-unsur sebagai sumber-sumber yang mempunyai hubungan fungsional yang teratur, tidak acak, dan saling membantu untuk mencapai suatu hasil (produk). Berbagai cara telah dikenalkan serta digunakan dalam proses belajar mengajar dengan harapan pengajaran dan pelatihan akan lebih berkesan dan lebih bermakna. Sistem dapat pula diartikan sebagai suatu himpunan atau perpaduan hal-hal atau bagian-bagian yang membentuk suatu kebulatan/keseluruhan yang kompleks atau utuh (Amirin: 1992). Sejak beberapa tahun belakangan ini 
teknologi informasi dan komunikasi telah banyak digunakan dalam proses belajar mengajar, dengan satu tujuan mutu pendidikan akan selangkah lebih maju seiring dengan kemajuan teknologi. Perkembangan teknologi desain grafis dan multimedia telah menjanjikan potensi besar dalam merubah cara seseorang untuk belajar, untuk memperoleh informasi, menyesuaikan informasi dan usaha bisnis di masyarakat.

Multimedia juga menyediakan peluang bagi pendidik untuk mengembangkan teknik pembelajaran sehingga menghasilkan hasil yang maksimal. Menurut McCormick dalam buku M.Suyanto (2005:21) Multimedia adalah kombinasi dari paling sedikit dua media input atau output dari data, media ini dapat audeo (suara, musik), animasi, video, teks, grafik dan gambar. Sedangkan menurut Hofstetter dalam buku M.Suyanto (2005:21) multimedia adalah pemanfaatan komputer untuk membuat dan menggabungkan teks, grafik, audeo, gambar bergerak (video dan animasi) dengan menggabungkan dan tool yang memungkinkan pemakaian melakukan navigasi, berekreasi dan berkomunikasi. Demikian juga bagi desainer grafis, dengan multimedia diharapkan mereka akan lebih menyerap informasi secara cepat dan efisien, mengingat proses belajar mengajar di tempat kerja seringkali dihadapkan pada kurangnya waktu untuk mengembangkan proses pembelajaran, sehingga untuk meningkatkan kemampuan kualitas kerja hanya terpaku dalam suasana media grafis cetak yang monoton, dan penawaran media baru bagi klien seringkali mengalami hambatan bagi munculnya ide atau gagasan kreatif untuk media elektronik di multimedia. Visualisasi adalah salah satu cara yang dapat dilakukan untuk mengkonkritkan sesuatu yang abstrak. Gambar dua dimensi atau model tiga dimensi adalah visualisasi yang sering dilakukan dalam proses pembelajaran, yang kini telah berkembang dalam bentuk gambar bergerak (animasi) yang dapat ditambahkan suara (audio) atau audio visual. Audio visual menjadikan visualisasi lebih menarik. Pembelajaran dengan mengembangkan media pembelajaran multimedia seperti ini dapat menyajikan sebuah tampilan berupa teks nonsekuensial, nonlinear, dan multidimensional dengan percabangan tautan dan simpul secara interaktif. Tampilan tersebut akan membuat pengguna (user) lebih leluasa memilih, mensintesa, dan mengelaborasi pengetahuan yang ingin dipahaminya.

Teknologi dan informasi memiliki sejumlah terminologi. Istilah ini sering diguanakan dalam dunia pendidikan dengan sebutan pendidikan teknologi, teknologi pendidikan, teknologi informasi, informasi dan tekonologi komunikasi, teknologi bidang pendidikan, tekonologi baru bidang pendidikan, keterampilan informasi, informasi buta aksara, dan informasi belajar. Kadang-kadang terminologi ini dikaitkan dengan keterampilan komputer, keterampilan komunikasi, komunikasi belajar, jelaslah kata terminologi ini sering membingungkan (Liliweri, 2011: 857). Everett M. Rogers, juga berpendapat tentang era komunikasi yang terjadi di muka bumi ini, yaitu: a) Era komunikasi tulisan, 4000 SM hingga sekarang, b) Era komunikasi cetak, 1456 hingga sekarang, c) Era telekomunikasi, 1844, hingga sekarang, dan d) Era komunikasi interaktif, 1946 hingga sekarang (Saefullah, 2013: 33).

Masa perkembangan komputerisasi terus berkembang sehingga melahirkan teknologi internet. Pesatnya perkembangan teknologi ini disebut "sebagai yang tidak terduga". Internet begitu memukau dan begitu cepat berkembang dengan varian-varian programnya yang menjadikan bumi ini dalam cengkraman tekonologi (Kholil, 2011: 24). Perkembangan teknologi ternyata juga diikuti oleh perkembangan pada jenis dan visual yang ditampilkan oleh papan reklame, reklame bukannya lagi hanya dalam pengertian sederhana seperti spanduk dan sejenisnya. Namun berkembang baik dalam ukuran maupun bentuk tampilan visualnya yang mengikuti kemajuan teknologi itu sendiri. Media iklan yang ditampilkan di areal luar ruangan (outdoor advertising) memiliki berbagai macam tipe, bentuk yang jumlahnya sangat banyak dan beraneka ragam, seperti : billboard advertising, baliho, megatron, videotron, neon box, pylon sign, spanduk, banner. Istilah dan nama diatas sebenarnya memiliki fungsi yang sama sebagai alat propaganda promosi, hanya dari segi bentuk, konstruksi, dan visualnya saja yang memiliki perbedaan.

Memiliki sebuah bisnis, tentu harus ada media promosi atau iklan. Ada banyak media promosi/iklan yang dapat digunakan untuk mendongkrak promosi penjualan, secara garis besar media iklan dapat dikelompokkan menjadi tiga bagian, yaitu iklan media cetak, iklan media elektronik dan iklan media luar ruang.

Perkembangan teknologi media periklanan telah semakin berkembang dari reklame konvensional menjadi papan reklame (billboard) digital dengan teknologi LED outdoor dan indoor. Pangsa pasar LED 
terus tumbuh hampir di setiap kota Indonesia. Para produsen semakin membutuhkan media beriklan berkualitas dengan resolusi lebih baik. Kebijakan pemerintah yang menganjurkan media outdoor saat ini agar ditata rapi. Kebijakan-kebijakan tersebut untuk menata kota yang saat ini sudah dijejali dengan papan-papan reklame konvensional di pinggir jalan. Pemasangan media LED dengan cara memasang di tempat yang tidak menjadi sampah-sampah visual dibuat lebih inovatif dan kreatif sehingga pemandangan iklan lebih menarik dan tertib terlebih jika menggunakan teknologi LED yang tidak statis.

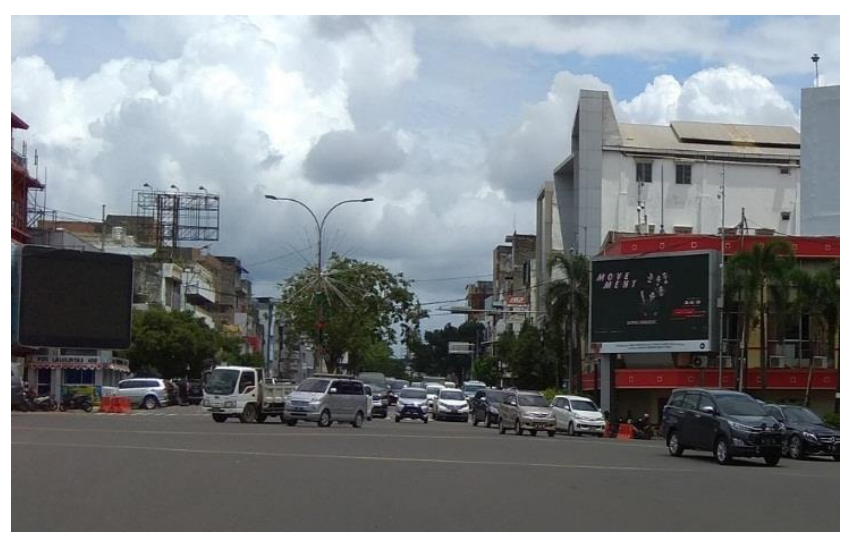

Gambar 1. Iklan LED Display Screen outdoor-Videotron, di Jl. Jend. Sudirman. Palembang. (Sumber Foto : Bobby Halim, 2018).

Iklan Videotron sudah mulai merambah dunia periklanan di Indonesia. Videotron sebagai salah satu jenis LED yang paling banyak digunakan di seluruh dunia. LED (Light Emitting Diode) menghadirkan berbagai macam keunggulan diantaranya LED screen, LED running text, LED display/papan video iklan, videotron dan mediatron. Videotron adalah LED screen yang bentuknya seperti televisi dengan ukuran yang jauh lebih besar dan tentunya mempunyai perbedaan besar yang bersifat mendasar.

Dunia percetakan saat ini mengalami perkembangan yang sangat cepat, dari mesin analog hingga mesin digital. Teknologi komputer yang ada sekarang, telah memungkinkan untuk mencetak secara terpadu yakni produksi cetak dalam satu mesin, dan hasil cetak tidak hanya sekedar teks, gambar sederhana, namun dapat mencetak dengan hasil high resolution. Perkembangan teknologi digital printing di masa mendatang sudah dipastikan akan "meledak" pada setiap area. Entah itu dalam aplikasi print on demand (PoD), digital imaging dan fotografi, large format printing (LEP) dan wide format printing, digital proofing, digital photolab, digital sablon (Anne, 2012). Potensi permintaan akan teknologi digital printing yang semakin meningkat dalam memenuhi kebutuhan disetiap kegiatan masyarakat. Wirausaha percetakan memiliki prosepektif pasar yang tidak pernah surut, sangat menjanjikan, dan menarik untuk digeluti, apalagi era milenial saat ini kebutuhan akan media promosi sangat dibutuhkan bagi, perusahaan, instansi, dan personal untuk mempublikasikan brand, produk, dan jasa agar dapat mencapai target tujuannya.

Digital printing F18 merupakan salah satu usaha digital printing yang terdapat di Kota Palembang, yang berada di Jalan Pimpong No. 18 Lorok Pakjo, Ilir Barat I, Palembang. Dwi Asa Verano selaku owner/pemilik Digital Printing F18 telah menggeluti usaha ini selama 11 tahun. Awal F18 ini bermula dari tempat cetak foto dan produk souvenir yang menggunakan garasi rumah pribadi, seiring waktu F18 mempunyai banyak pelanggan dan mulai terkenal dikalangan masyarakat umum dan berkembang menjadi perusahaan Digital Printing. Setelah satu periode berkecimpung di dunia percetakan, pertumbuhan pendapatan yang semakin meningkat dan konsumen pelanggan bertambah, hal ini dikarenakan F18 memiliki kelebihan kualitas media produk dan harga yang sangat terjangkau bagi konsumen dibandingkan dengan usaha sejenisnya yang berada di Palembang. Brand logo F18 yang terinspirasi dari nomor rumah dimana sebagai tempat mulainya usaha tersebut, menjadi simbol/lambang identitas perusahaan di bidang percetakan digital di Palembang. Tampilan logo F18 termasuk jenis Logotype, menampilkan simbol huruf " $F$ ", dan nomor "18", mencerminkan visi misi yang selalu fokus dengan tujuan dan selalu menjalin pertalian silahturahmi dengan konsumen. 
F18 digital printing sebagai wirausaha yang bergerak dibidang percetakan melayani berbagai media cetak grafis seperti : printing large format, outdoor/indoor vinyl printing, baliho, billboard, spanduk, hanging banner, roll up banner, stationery set, media propmosi, merchandise, printing media branding, packaging, dan desain grafis. Perkembangan teknologi dalam dunia periklanan saat ini menuntut kesiapan dari para pengusaha periklanan untuk selalu aktif disetiap kemajuan media yang ada, seperti halnya di F18 Digital Printing agar siap dengan kondisi tersebut yang dimana untuk menerima media LED Display Screen atau Videotron.

Berdasarkan latar belakang tersebut di atas maka pelatihan peningkatan keahlian program perancangan multimedia di f18 digital ini sangat penting untuk diadakan. Pelatihan yang akan dikembangkan dan diterapkan bagi para desainer grafis diharapkan akan memberikan wawasan baru dalam perancangan multimedia, mengingat minimnya para desainer grafis di kota Palembang yang belum menguasai dan memanfaatkan program ini.

Adapun wirausaha percetakan digital F18 Palembang yang menjadi sasaran kegiatan kali ini, dengan alasan bahwa para wiraswasta percetakan digital di kota Palembang selama ini banyak belajar secara otodidak dan hanya menerima final media desain elektronik atau multimedia dari klien, dan sedikit sekali merancang karya desain digital tersebut secara mandiri, serta masih jarang dijangkau program pengabdian pada masyarakat dari akademisi perguruan tinggu sehingga belum dapat merasakan kebermanfaatan program pengabdian secara langsung.

\subsection{Identifikasi Permasalahan}

Identifikasi permasalahan kegiatan yakni para pengusaha periklanan digital printing membutuhkan pelatihan untuk menambah wawasan mereka mengenai pengembangan media iklan elektronik multimedia yang lebih atraktif. Kemampuan para desainer grafis dalam merancang program multimedia yang interaktif dan atraktif masih harus ditingkatkan dan dikembangkan. Rumusan masalah dalam kegiatan ini adalah, sebagai berikut : Bagaimana upaya untuk melatih para desainer grafis di F18 Digital Printing mengenai perancangan media eletronik aplikasi dari multimedia yang interaktif dan atraktif dengan memanfaatkan Program Adobe Premiere ?

\subsection{Tujuan Kegiatan Pengabdian Pada Masyarakat}

Tujuan dalam kegiatan ini diarahkan untuk beberapa hal berikut ini : Peserta pelatihan mendapat tambahan wawasan ilmu pengetahuan tentang perancangan multimedia yang interaktif dan atraktif menggunakan program Adobe. Peserta pelatihan dapat menciptakan program multimedia dalam media LED Display Screen yang kreatif dan artistik.

\subsection{Manfaat Kegiatan}

Program pengabdian pada masyarakat ini diharapkan para peserta dapat mengetahui tentang arti pentingnya multimedia yang interaktif dan atraktif untuk meningkatkan kreatifitas dan para pengusaha periklanan di kota Palembang tidak ketinggalan informasi mengenai kemajuan iklan media elektronik saat ini. Terciptanya media-media elektronik yang dapat dimanfaatkan bagi masyarakat sebagai konsumen dan produsen produk atau jasa untuk mempromosikan yang lebih menarik, sehingga target audiens konsumen akan lebih termotivasi untuk menggunakan produk atau jasa yang ditawarkan.

\section{METODE PELAKSANAAN}

Pada bagian ini akan dikemukakan khalayak sasaran, metode kegiatan, langkah kegiatan, dan faktor penghambat-pendukung pelaksanaan program Pengabdian Pada Masyarakat ini.

\subsection{Khalayak Sasaran Pengabdian Pada Masyarakat}

Sasaran kegiatan ini adalah desainer grafis pada wirausaha advertising dan digital printing di kota Palembang, dan sebagai langkah awal dimulai dari F18 Digital Printing Palembang sebagai mitra program pengabdian pada masyarakat Tim UIGM. Pada prinsipnya program multimedia dari Adobe Premiere sangat bermanfaat untuk merancang media iklan indoor dan outdoor LED Display Screen. 
Jumlah peserta pelatihan ini merupakan karyawan divisi Desain Grafis sebanyak 10 orang yang berasal dari F18 Digital Printing Palembang.

Alasan dipilihnya mitra karena dijenjang ini diperlukan metode pelatihan yang lebih atraktif dan interaktif, dan banyak yang belum diperhatikan dengan baik. Disamping itu, alasan dipilihnya kota Palembang adalah faktor kebutuhan, karena dari pihak mitra sendiri sebelumnya telah mengajukan permohonan untuk dibimbing dan dilatih dalam pengenalan media LED Display Screen dalam teknis perancangan media desain grafis, dan faktor teknologi, karena perkembangan teknologi digital di kota Palembang cukup signifikan.

\subsection{Metode Kegiatan Pengabdian Pada Masyarakat}

Metode yang akan diterapkan dalam kegiatan ini adalah Presentasi, Pelatihan dan Praktek Langsung. Pelatihan diberikan beberapa kegiatan yang meliputi penyajian materi, dan praktik pembuatan media desain oleh para desainer grafis peserta pelatihan. Selanjutnya media desain yang telah dikerjakan oleh para peserta akan dikumpulkan, dikoreksi/dievaluasi, kemudian disempurnakan oleh tim PPM untuk kemudia dikembalikan lagi kepada peserta agar dapat diterapkan untuk multimedia.

Metode presentasi mengenai pengenalan software, fungis, manfaat, dan penerapannya dalam pembuatan media desain interaktif, metode demonstrasi mengenai pengoperasian program software dan metode praktik secara langsung perancangan desain.

\subsection{Langkah-Langkah Kegiatan Pengabdian Pada Masyarakat}

Adapun langkah yang telah ditempuh dalam kegiatan PPM ini mencakup beberapa tahap berikut ini :

1. Persiapan Kegiatan

a. Tahap persiapan merupakan tahap awal sebelum pelaksanaan PPM. Tahap ini ada beberapa hal yang dilakukan.

b. Koordinasi internal, dilakukan oleh Tim untuk merencanakan pelaksanaan secara konseptual, operasional, serta deskripsi tugas kerja masing-masing anggota.

c. Pemilihan peserta pelatihan.

d. Perekrutan peserta dipersyaratkan yang telah memiliki kemampuan yang memadai di bidang desain komunikasi visual, ilmu komputer, dan seni rupa.

e. Pembuatan instrumen pengabdian pada masyarakat, seperti lembar presensi, angket, lembar kerja.

f. Persiapan konsumsi, publikasi, lokasi, dan dokumentasi.

2. Pelaksanaan Pelatihan

Tahap ini merupakan tahap pelatihan yang diberikan kepada desainer grafis yang merupakan karyawan di F18 Digital Printing Palembang. Pelaksanaan pelatihan ini mencakup beberapa hal berikut :

a. Penyajian Materi

Materi yang disajikan terkait dengan pengenalan Iklan outdoor dan indoor LED display screen, penggunaan aplikasi program Photoshop dan Premiere untuk pembuatan desain multimedia. Penyajian ini dijadwalkan dalam 5 kali tatap muka. Penyaji materi adalah tim PPM UIGM disesuaikan dengan bidang keahlian masing-masing.

b. Materi Praktikum

Tugas akhir materi peserta diberi praktik sesuai materi yang telah disajikan untuk meningkatkan dan pemahaman materi serta melihat kreativitas dalam mendesain multimedia. Pelatihan ini para peserta ditugaskan untuk merancang satu media audio visual terkait bidang periklanan. Tim PPM UIGM mendampingi, memandu dan mengarahkan serta memberikan solusi apabila timbul permasalahan selama penugasan praktik.

c. Evaluasi Karya Desain Multimedia

Pada akhir pelatihan, media yang telah dibuat oleh para peserta dikumpulkan dan dinilai oleh tim PPM kemudian disempurnakan oleh tim PPM untuk kemudian dikembalikan kembali kepada peserta agar dapat digunakan untuk media latihan dalam mempublikasikan produk klien.

d. Penutupan Program Pengabdian pada Masyarakat 
Di akhir kegiatan peserta dan Tim melakukan diskusi dan sharing hasil pelatihan dan para peserta juga memberikan evaluasi pelatihan ini. Peserta mendapatkan koreksi dan evaluasi secara langsung terkait hasil karya mereka.

Setelah semua kegiatan yang telah direncanakan terlaksana, Ketua Tim PPM UIGM menutup program dan memberikan pesan kepada segenap peserta pelatihan untuk menerapkan apa yang telah didapatkan. Diharapkan program Pengabdian Pada Masyarakat yang akan akan datang program ini dapat dilanjutkan lagi dan dapat lebih menjangkau jumlah wirausahawan Periklanan dan Digital Printing lebih luas di Kota Palembang dan Provinsi Sumatera Selatan, sehingga manfaat program ini dapat dirasakan oleh pihak yang lebih banyak.

3. Evaluasi Kegiatan

Evaluasi kegiatan program Pengabdian pada Masyarakat ini dilakukan dengan beberapa cara. Evaluasi hasil dilihat dari tugas praktik para peserta yang ada. Hasil praktiknya dinilai dan hal itu menggambarkan keberhasilan materi yang telah disajikan. Selain itu, secara proses juga dicermati kinerja dan kesertaan para peserta. Akhir kegiatan Tim menjaring data dan penilaian program pada para peserta.

\section{HASIL DAN PEMBAHASAN}

Pelaksanaan program pengabdian pada masyarakat (PPM) meliputi hasil yang dicapai dan pembahasan, sebagai berikut :

\subsection{Hasil Pelaksanaan}

Materi yang tersajikan sebanyak tiga materi yang masing-masing disajikan oleh Tim PPM UIGM. Berikut tabel daftar materi dan pematerinya yang telah terlaksana dalam program PPM ini, yaitu :

Tabel 1. Daftar Jenis Kegiatan, Materi, Pemateri, dan Waktu Pelaksanaan

\begin{tabular}{|l|l|l|c|}
\hline \multicolumn{1}{|c|}{$\begin{array}{c}\text { Jenis } \\
\text { Kegiatan }\end{array}$} & \multicolumn{1}{|c|}{$\begin{array}{c}\text { Pokok Bahasan } \\
\text { (Materi) }\end{array}$} & \multicolumn{1}{|c|}{$\begin{array}{c}\text { Pemateri dan } \\
\text { pemandu }\end{array}$} & Waktu Pelaksanaan \\
\hline Presentasi & Periklanan, Iklan & Aji Windu Viatra, M.Sn & 19 November 2018 \\
& Outdoor dan Indoor & Bobby Halim, M.Sn & \\
& LED Komersial & K. Ghazali, M.Kom & \\
\hline Penyajian & Program Adobe & Aji Windu Viatra, M.Sn & 19 November 2018 \\
Materi & Premiere & Bobby Halim, M.Sn & 24 Nopember 2018 \\
& & K. Ghazali, M.Kom & 1 Desember 2018 \\
& & & 8 Desember 2018 \\
& & & 15 Desember 2018 \\
\hline Praktik & Multimedia, Program & Aji Windu Viatra, M.Sn & 19 November 2018 \\
& Adobe Premiere & Bobby Halim, M.Sn & 24 Nopember 2018 \\
& & K. Ghazali, M.Kom & 1 Desember 2018 \\
& & & 8 Desember 2018 \\
& & & 15 Desember 2018 \\
\hline
\end{tabular}

Pelaksanaan program ini melibatkan 3 mahasiswa Prodi Desain Komunikasi Visual agar kegiatan dapat berjalan lancar. Peran mahasiswa di dalam pelatihan ini adalah sebagai pemandu yang membantu para peserta dalam berpraktik dari meja ke meja. Jadi pada saat peserta berpraktik, para mahasiswa membantu mengarahkan dan memperjelas materi yang telah diberikan oleh pemateri secara langsung dalam perancangan multimedia.

Kegiatan sesi tanya jawab dilakukan bersamaan dengan penyajian materi. Para peserta dapat langsung berdiskusi dengan para pemateri secara langsung untuk memahamkan materi dan sharing pengalaman terkait dengan masalah yang tengah dibahas dalam materi bersangkutan. Kegiatan ini dilaksanakan di ruang kerja atau studio komputer grafis F18 Digital Printing dengan fasilitas yang representatif.

Kegiatan ini diikuti 8 peserta dari divisi desain grafis. Berikut daftar peserta pelatihan, sebagai berikut : 
Tabel 2. Daftar Nama Divisi Desain Grafis F18 Digital Printing

Peserta Pelatihan

\begin{tabular}{|c|l|l|}
\hline NO & \multicolumn{1}{|c|}{ NAMA } & \multicolumn{1}{c|}{ DIVISI KERJA } \\
\hline 1. & Fathun Qorib & Finishing Design \\
\hline 2. & Sobri Nopriadi & OP Design \\
\hline 3. & M. Naufal & Editing Desain Grafis \\
\hline 4. & Baka Saputra & Finishing Design \\
\hline 5. & Ahmad Satrio & Editing Desain Grafis \\
\hline 6. & Aldi Pratama & Finishing Design \\
\hline 7. & Paramitha Anisa & Adm Production \\
\hline 8. & Heriansyah & Production Design \\
\hline 9. & Marlin & Editing Design \\
\hline 10. & Syauqi Hafiz & OP Design \\
\hline
\end{tabular}

Para peserta pelatihan rata-rata telah menguasai teknologi informasi komputer dan komputer grafis, sehingga telah memiliki kemampuan aplikasi yang cukup memadai, sehingga tim pelaksana tidak terlalu kesulitan dalam memberi pengetahuan baru kepada peserta. Persyaratan ini memang telah sejak awal dicanangkan agar proses pelatihan dapat berlangsung tepat waktu, baik, cepat, dan praktis.

\subsection{Pembahasan}

Kreatifitas desainer grafis dalam bidang periklanan memiliki peran penting untuk menampilkan kualitas karya desain di setiap media, dengan pengolahan ide atau gagasan kreatif suatu dapat mencapai target dari publikasi yang dirancang. PPM ini dengan program pelatihan dapat meningkatkan wawasan dan pengetahuan yang selalu dikembangkan. Pemanfaatan teknologi di dunia periklanan masih kurang optimal khususnya di kota Palembang, kondisi ini dipengaruhi juga oleh kurangnya fasilitas penunjang pengembangan teknologi pembelajaran disamping sumber daya manusia yang menguasai teknologi masih kurang memadai.

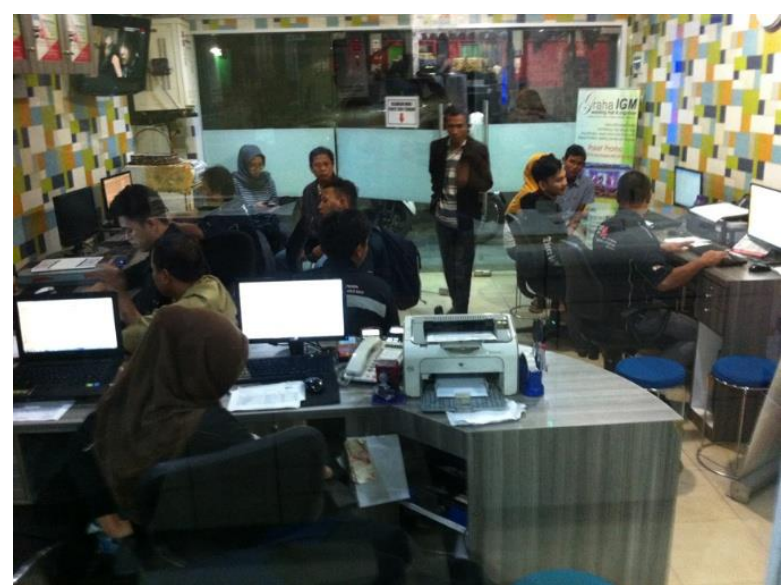

Gambar 2. Pelatihan Multimedia Adobe Premiere di Studio F18 Digital Printing Palembang. (Sumber Foto : Aji Windu Viatra, 2018).

Program pelatihan ini memberikan beberapa materi yang terkait dengan upaya pengembangan kualitas kreatifitas desainer grafis dalam multimedia iklan. Materi yang disajikan oleh Tim PPM UIGM dapat diterima, dicerna, dan dipahami peserta dengan baik. Metode pelatihan yang telah dilakukan cukup kondusif dengan pola pengajaran materi teori dan praktikum yang presentasenya lebih banyak. Dan efektifitas pelatihan didukung pula dengan kemampuan peserta di bidang komputer grafis, sehingga proses pengajaran lebih terjalin komunikasi secara interaktif. 
Diskusi yang dilaksanakan setelah pemaparan materi, dapat dilihat bahwa para peserta dapat memahami materi multimedia dan komputer grafis program Adobe Premiere secara baik, hal ini dapat dilihat dari hasil perancangan yang telah dilakukan. Kemampuan mengenal fungsi, tools, tips dan trik program Adobe Premiere mampu menciptakan karya desain multimedia dengan kreatif.

Evaluasi kegiatan yang dilakukan selama proses kegiatan berlangsung, yaitu pada saat peserta kegiatan melaksanakan proses pelatihan pembelajaran dengan Adobe Premiere. Teknik evaluasi dilakukan dengan cara observasi, yaitu melihat bagaimana kualitas karya yang dihasilkan. Melakukan wawancara yaitu memberi berbagai pertanyaan yang terkait dengan pelaksanaan kegiatan baik secara individu maupun secara kelompok.

\section{KESIMPULAN DAN SARAN}

\section{Kesimpulan}

Berdasar hasil pelaksanaan kegiatan pengabdian kepada masyarakat ini dan uraian pembahasan di atas, dapat disimpulkan beberapa hal sebagai berikut :

1. Pelatihan ini memberikan beberapa materi yang terkait dengan upaya meningkatkan kualitas perancangan multimedia dengan memberikan pengetahuan mengenai penggunaan dan pemanfaatan program Adobe Premiere yang kreatif, atraktif dan interaktif.

2. Materi wawasan dan praktikum pelatihan yang disajikan dapat diterima, dicerna, dan dipahami peserta dengan baik.

3. Kegiatan berlangsung lancar, tepat waktu dan sesuai dengan yang diharapkan dan para peserta dapat berkomunikasi dengan para pembicara dan peserta lain dengan baik.

\section{Saran}

Program pelatihan ini sangat bermanfaat dalam upaya meningkatkan wawasan dan pengetahuan para wirausahawan dan desainer grafis di periklanan dalam menyikapi perkembangan teknologi digital dan menghadapinya dengan sumber daya manusia yang berkualitas. Beberapa saran yang dapat diterapkan, yakni :

1. Program pelatihan perancangan multimedia sering diselenggarakan agar pola penyampaian materi pelajaran lebih menarik dan variatif.

2. Program ini dapat terus berlanjut sehingga lebih banyak lagi wirausaha digital printing di kota Palembang yang dapat merasakan manfaatnya.

3. Para peserta pelatihan diharapkan dapat ikut aktif berperan dalam meningkatkan kualitas iklan para klien dan mampu memberikan kualitas desain multimedia yang kompetitif sesuai dengan target produsen atau klien.

\section{UCAPAN TERIMA KASIH}

Tim Pengabdi Pada Masyarakat UIGM menyampaikan ucapan terima kasih yang sebesar-besarnya atas kerjasama dalam pelaksanaan kegiatan PPM tersebut, kepada :

1. Fakultas Ilmu Pemerintahan dan Budaya UIGM

2. Lembaga Penelitan dan Pengabdian Masyarakat UIGM

3. F18 Digital Printing Palembang

4. Para Mahasiswa Prodi Desain Komunikasi Visual

\section{DAFTAR PUSTAKA}

Amirin, Tatang M., 1992, Pokok-pokok Teori Sistem, Jakarta: Rajawali Pers.

Dameria, Anne. (2009). Digital Printing Handbook. Penerbit Link \& Match Graphics

Idris, Zahara dan Lisma Jamal. 1992. Pengantar Pendidikan, Jakarta: PT Gramedia Widia Sarana.

Kholil, S., (Ed), (2011). Teori Komunikasi Massa. Bandung: Ciptapustaka Media.

Liliweri, A., (2009). Dasar-Dasar Komunikasi Antarbudaya. Yogyakarta: Pustaka Pelajar Offset.

Saefullah, U., (2013). Kapita Selekta Komunikasi Pendekatan Budaya dan Agama. Bandung: Simbiosa Rekatama Media. 
M. Suyanto (2005). Multimedia Alat Untuk Meningkatkan Keunggulan Bersaing.Yogyakarta : Penerbit Andi.

https://www.adobe.com/sea/\#

Pertiwi, Wahyunanda Kusuma. (2018). "Ini Beda Panel LCD, LED, dan OLED”,

https://tekno.kompas.com/read/2018/08/29/19380027/ini-beda-panel-lcd-led-dan-oled 